\title{
Anida Manko
}

\section{KREATIVNO UČENJE U INKLUZIJI}

Sellman, Edward, ed., 2012. Creative Learning for Inclusion: Creative approaches to meet special needs in the classroom. New York: Routledge.

Kreativno učenje u inkluziji jedna je od knjiga iz serije Kreativno podučavanje / kreativne škole. Predstavljeni različiti načini rada koji su nastali u okviru engleskog programa Kreativno partnerstvo temelje se na praktičnim iskustvima i izazovima nastavnika, s fokusom na poticanje kreativnosti u radu s učenicima s teškoćama u razvoju. Stoga je ova knjiga svojevrstan vodič za nastavnike i stručne saradnike koji rade u inkluzivnom okruženju i nastoje osigurati da svaki učenik izrazi svoje sposobnosti u punom kapacitetu.

Osam poglavlja otvaraju prostor za promišljanje i kreiranje novih ideja u odgojno-obrazovnom procesu. Svako od njih donosi iskustva nastavnika i različite prakse u odgojno-obrazovnim ustanovama i svako je pisano rukom provoditelja aktivnosti. Prvo i drugo poglavlje nas uvode u šest različitih studija, u kojima se prikazuju praktični izazovi s kojima se susreću nastavnici, ali nude i konceptualna pitanja koja pozivaju na promišljanje o kreiranju poticajnog okruženja za učenike s teškoćama u razvoju. Navedene studije analiziraju različite aspekte: važnost mjesta i konteksta, specifičnost učenja u ranom uzrastu, održivost prakse, procjenu učenja, kreativne načine upotrebe tehnologije i učešće učenika. Autori pojašnjavaju zašto je kreativnost važna u kurikulumu, kako koristiti personalizirano učenje s učenicima s teškoćama u razvoju, načine poticanja motivacije i postignuća putem kreativnih iskustava, kao i kako inovirati kurikulum kroz upotrebu interaktivnih metoda poučavanja i alternativnih metoda komunikacije. 
U uvodu se pojašnjava kreativno učenje koje autori P. Thomson i J. Sefton-Green objašnjavaju kroz principe, gdje učenička kreativnost zavisi od kvalitete obrazovanja u kojem svaki učenik treba biti jednako prepoznat i uvažen. Nastavnici trebaju biti podrška, ali trebaju i prilagoditi rad i pratiti napredak svakog učenika. U tom procesu zadatak škole je investirati u usavršavanje nastavnika te graditi partnerstvo s kreativnim pojedincima i organizacijama, uz poticanje učenika na aktivno učešće u društvenim i kulturnim događajima.

Urednik E. Sellman u drugom poglavlju piše o kreativnim pristupima u inkluziji gdje naglašava da učenici s teškoćama u razvoju nisu homogena skupina te da navedeni primjeri i iskustva mogu biti samo prilika za kreiranje sličnih kreativnih pristupa u inkluzivnom okruženju. Svaka studija navodi na promišljanje o kontekstu, mjestu i okruženju učenja, kao i o kompetencijama nastavnika i njegovoj ulozi u kreiranju kreativnog kurikuluma, imajući u vidu učenike kojima je potrebna individualizacija i personalizacija u učenju. Zadaća nastavnika je upoznavati učenika svakoga dana i prilagođavati konvencionalni kurikulum i nastavne metode u skladu s obrazovnim potrebama učenika. Ova zadaća nastavnika izuzetno je važna uzmemo li u obzir činjenicu da je ranija praksa bila pomoći učeniku da se prilagodi kurikulumu, a ne obratno, što treba biti smisao inkluzije. Ovim se činom ukazuje na potrebu uključivanja učenika s teškoćama $u$ razvoju i učenju u procese odlučivanja i kreiranja programa rada. Sadržaji svih poglavlja polaze upravo od ideja kreiranja održivih pristupa koji će biti sveobuhvatni, zasnovani na partnerstvu, praktičnom radu i utemeljeni u zajednici gdje kreativnost igra ključnu ulogu u pokretanju novih perspektiva u odgoju i obrazovanju.

Poglavlje Kreativna školska organizacija i kurikulum autora R. Irelanda kroz inovativni pristup razvoja predstavlja inkluzivne školske zajednice i kurikulum u Darlington Education Villageu. U proces promjene bile su uključene osnovna, srednja i specijalna škola koje su premještene u novo pristupačno okruženje. Integracija triju škola u jednu zajednicu dovela je do potrebe prilagodbe i razumijevanja različitih kultura koje je svaka od škola donijela u novo okruženje. Menadžment Education Villagea odlučio je razviti holistički pristup gdje će svaki učenik biti u centru zbivanja. Filozofija inkluzije počivala je na konceptu personalizacije i vjerovanja da svaki učenik treba imati pristup kurikulumu koji će biti zasnovan na 
individualnim potrebama i stilovima učenja svakog učenika. Kurikulum je kreiran na osnovu inicijalne evaluacije u kojoj su pored nastavnika bili uključeni roditelji i učenici mlađih i starijih uzrasnih grupa. Ovakav pristup su temeljili na modelu Opening Minds gdje su učenici učestvovali $\mathrm{u}$ realizaciji nastavnih tema u okviru nastavnih predmeta: Matematika, Nauka, Umjetnost i dizajn, Dizajn i tehnologija, Jezici i Muzička kultura. Svaku temu je realizirao drugi nastavnik tema što je omogućilo raznovrsne pristupe nastavnika, ali i međusobnu saradnju kako nastavnika tako i učenika. Cilj programa je razvijanje vještina putem reorganizacije kurikuluma. Program je omogućio da učenici postanu aktivni učesnici u timskom radu gdje su razvijali kreativno mišljenje, ali i samostalnost. To su postigli kroz ohrabrivanje učenika, dodatno osnaživanje jakih strana, fokusirajući se na osobnost i povezujući nastavne teme sa životnim iskustvom. Nastavnici su nakon ovog programa nadograđivali i kreirali nove kroskurikularne programe kojima su jačali ideju inkluzivne zajednice.

Poticanje kreativnosti u ranom uzrastu je poglavlje u kojem A. Hallowes i A. Shimmin predstavljaju inkluzivnu praksu u predškolskoj ustanovi. McMillan Nursery School se 2006. godine reorganizira u Dječiji centar koji pruža cjelodnevnu podršku djeci. Posebno nude podršku djeci kojoj je potreban rad u manjim grupama ili individualni rad. Ostvarili su saradnju s Creative Partnershipom u namjeri da proaktivno razvijaju te potiču rast i razvoj djece, uz stimulisanje kreativnijeg rada i bolje saradnje s partnerima. Kroz dugoročnu saradnju shvatili su da je poticanje kreativnosti složen proces, gdje je bitno pronaći balans između kontroliranih situacija i onih u kojima je sve dopušteno, do mjere da ne postoje granice, da je svako ponašanje prihvatljivo i da su sve ideje sjajne. Počeli su s projektom Eyes Wide Open; namjerno su dali ovaj naziv da ih stalno podsjeća da očekuju neočekivano i da svaki dan tragaju za novim načinima u kojima će uključiti svu djecu. Primarno su tragali za ranijim iskustvima i alternativnim modelima predškolskog odgoja. Tako su se upustili u eksperiment zasnovan na poznatom Reggio pristupu. Kreirali su listu kreativnih karakteristika u učenju identifikacijom problema, upotrebom divergentnog mišljenja, kooperativnog učenja, riskiranja, ali i balansa između vještina i izazova koje su nastavnici koristili u daljnjem planiranju aktivnosti. Rezultati su bili vidljivi, mada se program nadograđivao i dalje. U rad su uključili i praktičare iz oblasti kreativnosti kroz eksperimente, debate, posjete i diseminacijske 
aktivnosti. Koristili su mogućnost snimanja kamerom, što su kasnije mogli proslijediti roditeljima i nastavnicima da prate nove načine podučavanja, ali i da opserviraju napredak i rad učenika. Vođeni idejom da svako dijete najbolje zna koje interese ima, na koji način voli učiti i na koji se način najbolje izražava, prilagodili su kurikulum na način da učenicima nude više slobode, fokusiraju se na personalizirano učenje, koriste vizualne alate $\mathrm{i}$ potiču osoblje da uvijek identificiraju naredni korak. U ovom su procesu vrijeme, volja i želja, kao i partnerstvo bili ključni elementi za uspjeh što se pokazalo i u novim idejama koje žele implementirati kroz buduće aktivnosti.

Autor M. Scoot u petom poglavlju opisuje partnerstvo između Brays Special Schoola i Creative Partnershipsa. Ključna odrednica partnerstva je održivost. Godine 2002. ostvarili su partnerstvo, međutim, odnosilo se samo na određene aktivnosti. Shodno tome, odlučili su proširiti djelovanje na cijelu školu, što su napravili 2006. godine kroz angažiranje umjetnika, pisca i uključivanje učenika u rad teatra. Time je projekat osigurao različite načine učenja kroz pisanje priča, istraživanje, igre uloga, transformacije i kreacije. Poseban naglasak bio je na diferencijaciji, razvoju osjetila i učeničkih reakcija na različite materijale koji su korišteni u pripremi aktivnosti. Projekt je baziran na nekoliko strategija partnerstva: odgovornosti svih članova; planiranju/predviđanju mogućih izazova; odgovoru na prepreke; razvijanju osnovnih vještina; potrebnom vremenu za opservaciju, evaluaciju i pauzu te za slušanje i pozitivnu povratnu informaciju. Ključno je razgovarati, dijeliti priče i uspjehe, uzajamno podržavati nastavnike i učenike, posebno prihvatajući činjenicu da su i prepreke važne za svaki proces. Navode da je važno vraćati se na prvobitnu ideju i promišljati o napravljenim koracima, ali i o onim koji slijede da bi projekat bio uspješan.

Šesto poglavlje donosi iskustva u kojem autori W. Johnson i A. Sloan predstavljaju način rada iz škole koja radi s učenicima s autizmom, Rosehill Special School. Fokus rada stavljen je na planiranje i postignuće, posebno na postignuća onih učenika koji ne mogu artikulirati ono što nauče na uobičajen način. Pored toga predstavljaju na koji način raditi s učenicima kojima je potrebna podrška u bilo kojem smislu s naglaskom na pripremu vizualnih materijala koji će olakšati procese učenja i poticanja kreativnosti. Učenicima s autizmom treba osigurati okruženje i uspostaviti strukturu što može biti izazov kada postoji cilj da se kreira i potiče kreativno 
učenje. Međutim, ova je škola nastojala osigurati razne prilike za kreativnost kako u radu nastavnika tako i u radu učenika. Odlučili su napustiti tradicionalne metode podučavanja, te su učenicima osigurali da istražuju cijeli prostor škole, ne samo učionicu u kojoj bi inače boravili. Ključne promjene su krenule od opserviranja i zapisivanja ključnih trenutaka u učenju. Projekat je započeo 2004. godine gdje su odlučili osigurati multisenzorno i interaktivno okruženje za učenje. To su postigli kroz detaljnu refleksivnu praksu i obuku tima, s namjerom da sami nastavnici propituju svoje načine podučavanja učenika. Prije saradnje s Creativ Partnershipom ostvarili su saradnju sa stručnjacima i ustanovama kulture iz lokalne zajednice u namjeri da prošire resurse kojima će poticati kreativnost. Projekat Big Arts jedna je od aktivnosti kojom su poticali učenike da razvijaju osjetila istražujući različite materijale $u$ dvodimenzionalnim i trodimenzionalnim oblicima. Pored toga radili su na jačanju načina komunikacije s učenicima s autizmom upotrebom simbola, fotografija, vizualnih prikaza i scenarija za one učenike koji ne govore. Nastavnici su posebno trebali biti osjetljivi na učenike koji ne komuniciraju putem govora, te su pratili govor tijela i ponašanja koji su jedan od načina kako učenici ispoljavaju svoje potrebe. Stoga je opservacija svakodnevnih aktivnosti vrlo važan segment u daljnjem planiranju aktivnosti. Autori navode primjer opservacije što može biti korisno za sve nastavnike. Koraci koje su proveli da bi osigurali kurikulum koji će poboljšati vještine i interese kod učenika temeljio se na: opservaciji, zapisivanju/snimanju stanja, refleksiji, planiranju i ponovnoj opservaciji. Nastavnici su razvijali svoje kompetencije tokom obuka u kojima su imali podršku drugih stručnjaka, koristili su i videozapise iz kojih su mnogo toga učili i primjenjivali u budućem radu. Upravo stručnjaci i praktičari iz srodnih i istih oblasti mogu motivirati nastavnike, donijeti nove perspektive i ideje za buduće ciljeve koje škola želi postići. Nakon što su uvidjeli benefite opservacije, navode nekoliko savjeta i preporuka kako pravazići određene izazove, što može biti ideja i za druge nastavnike koji rade s učenicima s autizmom. Ova je škola napravila i korak dalje u polju opservacije, kreirajući okruženje u novoj zgradi škole na način da učionice imaju prozor za opservaciju gdje nastavnici mogu pratiti rad učenika i istovremeno komunicirati s ostalim nastavnicima bez da ometaju učenike.

Angažman učenika s oštećenjem sluha putem informacijsko-komunikacijskih tehnologija (ICT) je poglavlje u kojem S. Hawes i dr. opisuju kako 
omogućiti aktivno učešće učenika u procesu učenja razvijajući samostalnost i samopouzdanje uz upotrebu tehnologije. U poglavlju su predstavljene dvije studije gdje se opisuje koje su koristi, ali i izazovi upotrebe ICT-a. Prva studija govori o učeniku Richardu koji je imao priliku da uči i pokaže šta je naučio tako što je dobio zadatak da producira film. Pored toga što se mogao izraziti na drugačiji način, učenik je stekao nove vještine. Druga studija prikazuje tranziciju iz osnovne u srednju školu i načine upotrebe asistivne tehnologije. Aleks je učenik koji je nakon neuspješnih strategija koje su nastavnici primjenjivali dobio priliku da uči i da se izrazi putem snimanja i postavljanja svog rada na blog. Glavni cilj obje studije bio je razumjeti procese učenja učenika koji koriste znakovni jezik, kao i pomoći učenicima da poboljšaju svoje učenje, da budu kreativniji i efikasniji. Time su nastojali osigurati prilike da učenici demonstriraju ono što uče i nauče na način koji sami odaberu.

Posljednje poglavlje govori o kreativnim načinima izražavanja potreba u i izvan škole s ciljem podizanja svijesti i ukazivanja na postojanje stereotipa u zajednici. Rezultat toga je i učešće učenika u donošenju odluka i učešće u diskusijama i konferencijama. Autori M. Kirby i D. Stewart navode primjere u kojima učenici putem izbora, stvaranja odnosa i prijateljstva postižu bolju kvalitetu života. Da li će učenici imati priliku izraziti svoje potrebe zavisi i od podržavajućih kulturoloških faktora, odnosno od otvorenosti, očekivanja, okoline, razumijevanja nastavnika i podrške obitelji. Program koji je proveden doveo je do novih ideja i jačanja veze s osnovnim i srednjim školama u kojima i dalje nastoje razvijati pozitivne stavove prema inkluziji, te veća očekivanja koja se odnose na angažman učenika u široj zajednici.

Na kraju svakog poglavlja autori navode korisne izvore koji mogu nastavnicima koristiti u planiranju neke od aktivnosti. Ponuđeni izvori obiluju mnoštvom primjera i praksi koje su spomenute u knjizi. Navedenim primjerima i ponuđenim izvorima nastavnicima i svima koji rade u odgoju i obrazovanju nude se inspirativne ideje kako osigurati da se svaki učenik osjeća korisnim i uspješnim u onom što uči i radi kako u školi tako i u zajednici. 